PROCEEDINGS, INDONESIAN PETROLEUM ASSOCIATION

Thirty-Third Annual Convention \& Exhibition, May 2009

\title{
MIDDLE-LOWER EOCENE TURBIDITES: A NEW DEEPWATER PLAY CONCEPT, KUTEI BASIN, EAST KALIMANTAN, INDONESIA
}

\author{
Wayne K. Camp* \\ Elly E. Guritno* \\ Deden Drajat* \\ Moyra E. J. Wilson**
}

\begin{abstract}
Upper Miocene turbidites are a proven oil and gas play in the deepwater Kutei basin where over six tcf of gas and 200 million barrels of oil have been discovered to date. Pre-Miocene objectives are largely beyond the reach of the drill bit in most of the deepwater Kutei basin, except along an uplifted area south of the Mangkalihat Peninsula. Here Middle to Lower Eocene turbidite deposits are penetrated by a few wells and also exposed onshore. A regional integrated outcrop, core, petrographic and micropalaeontological study has constrained basin evolution, depositional history and the potential for petroleum system development.
\end{abstract}

Two main turbidite facies types are interpreted: 1) thin-bedded, low net-to-gross distal turbidites and 2) thick-bedded, high net-to-gross proximal turbidites. The distal turbidites are fine-grained arkosic arenites with limited reservoir potential. The proximal turbidites include fine- to coarse-grained, friable and porous, quartz-rich sandstones that form the primary reservoir objective.

Oil produced from onshore Miocene marine sandstone reservoirs and sampled surface seeps along the southern Mangkalihat Peninsula indicate a non-marine source rock. Basin modeling studies show that the top of the oil window is at about 2400 $\mathrm{m}$, indicating Eocene or older source rocks. The presence of non-marine kerogen is thought to have been derived from transported organic matter deposited as organic-rich laminations within turbidite sandstone and mudstone deposits, similar to source rock models proposed by others for the Kutei basin Upper Miocene deepwater turbidite play.

* Anadarko Indonesia Company

** Curtin University
A period of east-west compression during the Miocene to Pliocene resulted in reactivation of northwest- and northeast-trending faults creating a series of basin inversion anticlines along the margins of Eocene half grabens. A thick interval of Oligocene bathyal shale was deposited in the basinal areas flanking Oligocene carbonates deposited on the Mangkalihat platform, with the shale forming a regional top seal for the Eocene play.

\section{INTRODUCTION}

There are proven petroleum systems in several Paleogene rift basins in Indonesia (Howes, 1997; Doust and Noble, 2008). These are characterized by syn-rift terrestrial source rocks overlain by fluvial to marginal marine clastic and shallow marine carbonate reservoirs. Exploration for marine Eocene syn-rift petroleum systems has been limited primarily due to the perceived lack of: 1) high quality (particularly oil-prone) source rocks and 2) high quality reservoir rocks deposited in outer shelf settings.

New source rock models, such as Peters et al. (2000), have provided a better understanding on the controls of source rock potential in marine outer shelf and slope settings for the Miocene in the Kutei basin. Recent drilling in the deepwater Kutei basin has confirmed the presence of high quality, oilprone source rocks associated with transported terrigenous kerogen deposited within Upper Miocene turbidite sandstones (Saller et al., 2006). Over six tcf of gas and 200 million barrels of oil have been discovered to date from primarily Upper Miocene turbidite sandstone reservoirs in the deepwater Kutei basin (Guritno et al., 2003; Saller et al., 2006).

The purpose of this paper is to outline the play elements for a new deepwater Kutei basin play. 
Middle to Lower Eocene turbidite reservoirs and source rocks are targeted analogous to the proven Upper to Middle Miocene turbidite deepwater Kutei basin play.

\section{Location}

Due to the great thickness of Neogene deposits over much of the Kutei basin, knowledge of the nature and extent of Eocene syn-rift deposits is restricted to outcrop and well data from exposed and shallow buried regions along the western and northern margins of the basin. The Eocene turbidite play area outlined in this paper is located in Sangkulirang Bay, to the south of the Mangkalihat Peninsula, within an uplifted area in the northern Kutei basin (Figures 1 and 2). Water depths gradually increase south of the coastline to about $1000 \mathrm{~m}$ beyond which water depths rapidly increase along the highly dissected northwest-trending Sangkulirang escarpment to over $2500 \mathrm{~m}$ on the abyssal plain. The deepwater Eocene turbidite play encompasses an area of approximately $5180 \mathrm{sq} \mathrm{km}$ extending from the present shelf margin to the Sangkulirang escarpment (200-2000 m water depth).

\section{GEOLOGIC SETTING}

The Kutei basin is located in eastern Kalimantan (Borneo) where an estimated 12-15 km of sediment thickness has accumulated in the depo-center near the present day Mahakam delta since the Eocene (Chambers et al., 2004). The basin extends over 300 $\mathrm{km}$ from the western limits of Tertiary outcrops eastwards into the Makassar Strait abyssal plain (Figure 1). The Kutei basin is bounded to the north and south by structurally high blocks of the Mangkalihat Peninsula and Paternoster platform, respectively.

\section{Basin History}

The origins of the Kutei basin are controversial, though extension is associated with separation of eastern Borneo from western Sulawesi and formation of the Makassar Strait during the early Paleogene. Rifting may be a lateral extension of sea-floor spreading in the Celebes Sea (Hall, 2002), although it is unclear whether oceanic crust formed in the Makassar Strait. A series of half graben basins developed in response to this rifting episode and were filled with Eocene syn-rift deposits.

Basin subsidence during the Late Eocene to Oligocene resulted in a marine transgression and deposition of carbonates on elevated platform margins, such as on the Mangkalihat Peninsula (Wilson et al., 1999) and locally on Eocene halfgraben basement highs (Guritno and Chambers, 2000; Moss and Chambers, 1999), with bathyal clastics deposited in the basin centers. Important northwest-southeast trending lineaments (probably reactivated basement faults) segmented the region and controlled regional deposition patterns during the Late Oligocene to Early Miocene (Wilson et al., 1999; Wilson and Evans, 2002; Chambers et al., 2004).

Uplift and erosion in central Borneo during the Early Miocene resulted in a series of deltas that prograded westward, filling the Kutei basin to the present shelf margin and supplying turbidite deposits on the slope and abyssal plain (Moss and Chambers, 1999). Regional compression that began at the end of the Early Miocene reactivated earlier formed basement faults creating basin inversion structures in the northern Kutei basin (Chambers et al., 2004) and on the southern Mangkalihat uplift.

\section{Stratigraphy}

Eocene rocks crop out west of the Mangkalihat Peninsula where they are exposed within the cores of northeast-trending anticlines and onlap preTertiary metasedimentary basement along the Suikerbrood Ridge (Sukardi et al., 1995). Isolated Eocene exposures also occur along the northeast tip of the Mangkalihat Peninsula (Djamal et al., 1995), and the Eocene has been penetrated by several key wells (Figure 3).

Rapid lateral facies changes within and between fault-bound rift basins, and poor paleontological control, have resulted in a complex stratigraphic nomenclature for the various informal Eocene lithostratigraphic units in the northern Kutei basin and Mangkalihat Peninsula. Regional studies such as Sunaryo et al. (1988); van de Weerd and Armin (1992); Moss and Chambers (2000); and Feriansyah et al. (2000) have aided in the understanding of the Eocene depositional systems. In general, Middle Eocene deposits exhibit a progressive basinward lateral facies change from predominately nonmarine in the west (Keham Haloq Formation, Guritno and Chambers, 2000) to deltaic (Beriun Formation, Satyana and Biantoro, 1996) and bathyal turbidite deposits (Malio Mudstone, Wilson et al., 2007) in the east (Figure 4).

Middle to Lower Eocene sandstone is found near the base of the Birah-1 and Makassar-A1 wells 
below a Middle Eocene marine shale unit that is correlative with the Malio mudstone in the northwest Mangkalihat Peninsula (Figure 4). Microfossils recovered from shale interbedded with the sandstone in the Birah-1 well indicates an Early Eocene age (nannofossil zone CP10) or older for the sandstone unit that is correlated with the Sambakung Formation. The base of the Sambakung Formation was not penetrated in the wells, but elsewhere the Sambakung Formation rests unconformably on pre-Tertiary metasedimentary basement (Achmad and Samuel, 1984).

\section{SOURCE ROCK}

Pre-World War II oil and gas production from shallow wells and surface seeps in the southwest Mangkalihat Peninsula attest to the presence of thermally mature source rocks onshore. These extend south into the shallow offshore area based on hydrocarbon shows from Eocene sandstones in the Makassar-A1 and Birah-1 wells. Widespread thermogenic gas seeps sampled by seafloor cores (Decker et al., 2004) further extend the known presence of thermally mature source rocks into the southern limits of the Mangkalihat uplift.

Geochemical analyses from outcrop and well samples in the southwest Mangkalihat Peninsula show the marine shales are typically lean and gas prone. For example, total organic content (TOC) from the Paleogene below $1400 \mathrm{~m}$ in the Sembulu- 1 well range from 0.12 to $0.44 \mathrm{wt} \%$ and 0.36 to 0.71 wt \% below $1523 \mathrm{~m}$ in the Kariorang-1A well, and thus are not considered as potential source rocks. Oligocene to Middle Miocene marine shale (Kariorang and Maluwi Formations) have an average TOC range from 1.0 to $2.1 \mathrm{wt} \%$. The marine shales are dominated by terrestrially derived (type III) kerogen with a Rock Eval measured Hydrogen Index below $200 \mathrm{mg} \mathrm{HC} / \mathrm{g}$ TOC indicating a gas prone Oligocene-Miocene source interval.

Good quality, terrestrial coaly Eocene source rocks are known from the onshore Kutei basin and West Sulawesi region (Curiale et al., 2002; Curiale and Decker, 2007). An influence of non-marine lacustrine type source rock is inferred in the Maau-1 and Wahau-1 wells, onshore Kutei basin (Guritno and Chambers, 2000). A lacustrine, algal-rich source rock may have formed in ephemeral lakes within the general deltaic to marginal marine setting. Alternatively lacustrine conditions may have developed during initial filling of half graben basins when rates of subsidence exceeded sedimentation.

Geochemical analyses of Miocene crude oils and source rocks in the Kutei basin indicate the majority of produced oils are derived from terrestrial, coaly source rocks (Paterson et al., 1997; Longley, 2005; Saller et al., 2006). The nearest thermally mature coaly source rocks occur within the Middle Miocene deltaic facies of the Balikpapan Formation to the southwest in the Sangatta field area (Fukasawa et al., 1987). This potential source is not considered as the likely source for Eocene oil shows on the southern Mangkalihat uplift due to stratigraphic position and required long distance migration of over $50 \mathrm{~km}$ (Figure 3).

The source of hydrocarbons for the proven Miocene turbidite play in the deepwater Kutei system to the south (Figure 1) is terrestrial-derived organic matter transported from the delta into deepwater (Dunham et al., 2000; Guritno al., 2003; Lin et al., 2005; Saller et al., 2006). Organic material was transported mainly during lowstand periods and is deposited within turbidite sandstones. Detailed geochemical sampling of cores confirms that the source material is dominantly associated with sandstone and siltstone, rather than shale. If extensive peat swamps were developed during the Middle-Lower Eocene, a comparable source material transport mechanism might be expected for the Eocene turbidite play.

\section{Eocene Potential}

Vitrinite reflectance data and basin modeling show that the Oligocene and younger marine shales on the Mangkalihat uplift are thermally immature. An Eocene or older source is therefore inferred for known hydrocarbon occurrences on the southern Mangkalihat high.

Poorly exposed lignite and carbonaceous mudstones cropping out on the northeast Mangkalihat Peninsula are most likely Middle to Late Eocene in age based on palynology (Wilson and Evans, 2002; Noon et al., 2003). However, a mixed carbonatesiliciclastic succession closely associated with the lignites may vary in age from Late Eocene to Late Oligocene and organic-rich units may range into the Oligocene. The Mangkalihat lignites contain humic, oil and gas prone kerogen that could be precursor oil and gas prone source rocks (Noon et al., 2003).

The Middle Eocene Malio Mudstone outcrops on the northwest Mangkalihat Peninsula include pyriterich carbonaceous mudstone intervals estimated to 
contain 0.5-2 wt \% TOC. Abundant organic detritus highlights parallel- and ripple cross-laminations in fine-grained sandstone and siltstone turbidite beds. Sidewall core descriptions from the Middle Eocene in the Birah-1 well report black, pyritic mudstone with lignite streaks at $2110 \mathrm{~m}$ and very thin laminations of black, hard lignitic material in very fine-grained sandstone at $2152 \mathrm{~m}$.

The carbonaceous laminations within the Malio Mudstone outcrop and Birah-1 well are similar to coaly laminations in carbonaceous sandstones described from cores of Upper Miocene turbidite deposits by Saller et al. (2006) that are thought to be the main source rock facies for the deepwater Kutei basin oil and gas fields. There is insufficient geochemical data to characterize the source rock potential of the Eocene on the Mangkalihat uplift. However, transported coaly organic matter deposited in Middle to Lower Eocene turbidite deposits are thought to be potential oil and gas source rocks based on analogy with the Upper Miocene deepwater Kutei basin play. The MiddleLower Eocene represents the best source rock candidate to explain Middle-Lower Eocene oil shows in sidewall cores from the Makassar-A1 and Birah-1 wells, and theromogenic gas shows in deepwater seafloor cores based on thermal maturity and stratigraphic position.

\section{RESERVOIR}

Middle to Lower Eocene sandstones penetrated in the Makassar-A1 and Birah-1 wells are prospective reservoir objectives on the southern Mangkalihat uplift (Figure 5). These sandstones are interpreted as turbidite deposits based on the presence of bathyal benthic foraminifera and regional facies correlations. In the Makassar-A1 well, the top of the Eocene turbidite sandstone interval is at $2324 \mathrm{~m}$ with over $457 \mathrm{~m}$ of net sandstone (48\% net-togross). Measured porosity from percussion sidewall cores range from 17 to $25 \%$ with nearly $122 \mathrm{~m}$ of porous sandstone ( $>10 \%$ porosity) measured from porosity logs.

The sandstones are poorly- to moderately-sorted lithic arenites and arkosic arenites (Folk, 1974). Grain size ranges from very fine to very coarse sand. The dominate porosity type is primary intergranular and secondary dissolution of feldspar and lithic grains. Cements include quartz overgrowths, authigenic kaolinite, calcite and ferroan dolomite. The coarser-grained sandstones are weakly cemented and are commonly observed as loose sands grains in well cuttings, and have the best reservoir quality. The finer-grained sandstones are better indurated, and reservoir quality is significantly reduced due to detrital clay matrix and compacted volcanic lithic fragments.

Two types of sandstone facies are interpreted based on electric log character: 1) thin (9-15 m thick) fining upward intervals interpreted as leveeoverbank deposits (distal fan), and 2) blocky units (6-27 m thick) with sharp basal contacts and finingupward tops interpreted as channel and sheet deposits (proximal fan).

The distal turbidites are fine-grained arkosic arenites with limited reservoir potential. The proximal turbidites include fine- to coarse-grained, friable and porous, quartz-rich sandstones that form the primary reservoir objective. Near the base of the Makassar-A1 well, interpreted amalgamated proximal fan deposits are vertically stacked into a $100 \mathrm{~m}$ thick sandstone interval (Figure 5).

\section{TIMING AND MIGRATION}

A 3D basin model was constructed to evaluate thermal maturity of potential source rock horizons and migration pathways in the offshore Mangkalihat uplift area. The thermal history model was constrained by corrected bottom hole temperature data from the Birah-1, Makassar-A1 and Pagar-1A wells The resultant geothermal gradient used in the model was $2.2{ }^{\circ} \mathrm{F} / 100 \mathrm{ft}$. The top of the predicted oil window (0.7 \%Ro) is modeled at approximately $2500 \mathrm{~m}$ with the top of the dry gas window (1.3 $\%$ Ro) at about $3700 \mathrm{~m}$.

Based on regional isopach maps and burial history plots, post Eocene rocks have never been buried sufficiently on the Mangkalihat uplift to have generated hydrocarbons (Figure 6). However, Middle Eocene and older rocks are thermally mature over large areas offshore the southern Mangkalihat Peninsula at present burial depths.

Potential Middle to Lower Eocene turbidite source rocks within the half graben depocenters entered the oil window by the Early Miocene (approximately $17 \mathrm{Ma}$ ) and are presently oil and gas mature (Figure 6). Where the synrift Eocene thins over a basement ridge along the Sangkulirang escarpment it is thermally immature.

Potential hydrocarbon migration pathways mapped at various levels within the Eocene indicate that the mapped structures have adequate access to the mature source kitchens to have been charged with 
oil and gas. Early formed structures (e.g., pre-Early Miocene) have the greatest chance of trapping oil expelled from potential Middle to Lower Eocene source rocks. Late structures (Pliocene) have higher risk as they post date peak oil expulsion.

\section{STRUCTURE}

Numerous potential structural traps have been mapped in the offshore Mangkalihat uplift based on 2D seismic, gravity and magnetic data. The area is dominated by two structural trends; northwest and northeast. These trends appear to be inherited from basement faults formed during Early Eocene rifting and inferred basement weakness zones parallel to basement accretion trends along the southeast Sundaland Mesozoic core. Several shallow folds in the Miocene overly the basement faults and are interpreted as basin inversion structures associated with reactivated basement faults (Figure 7).

Eocene synrift isopachs are unreliable in determining the trends of the half graben basins due to the inability to accurately map the top of the preTertiary basement from vintage 2D seismic data. Based on gravity and magnetic data, Decker et al. (2004) interpret northeast-southwest oriented rift basins that are perpendicular to the inferred extension direction during the Early Eocene opening of the Makassar Strait.

The northwest-trending structures parallel the Sangkulirang escarpment, a basement ridge that appears to extend onshore to the Karangan River lineament. The Karangan River lineament is subparallel to the Bengalon River lineament to the southwest that is interpreted by Chambers et al. (2004) as a basement-rooted, down-to-the-south extensional fault zone active during the Late Oligocene to Early Miocene. Uplift along the Sangkulirang fault zone post dates Eocene rifting based on the presence of thick Middle and Lower Eocene synrift clastics penetrated in wells upthrown (north) of the fault.

A prominent unconformity is observed on 2D seismic lines in the southern Mangkalihat uplift (Figure 7). Middle Eocene and older units are folded and faulted below the angular unconformity. High amplitude seismic reflectors tied to carbonates dated as Upper Eocene (nannofossil zone CP15) in the Birah-1 and Makassar-A1 wells onlap the erosion surface and thus constrains the age of the unconformity as no younger than Late Eocene (3537 Ma, Gradstein et al., 2005).
The Upper Oligocene interval present in the Makassar-1A well is absent in the Birah-1 well (located only nine kilometers to the east) and the Lower Miocene rests directly on the Lower Oligocene. This Late Oligocene hiatus is not as pronounced on seismic lines as the Late Eocene angular unconformity in the offshsore Mangkalihat uplift, but the disconformity can be recognized by onlapping seismic horizons (Figure 7). This unconformity correlates with a regional unconformity associated with uplift and volcanism that has been dated at $26 \mathrm{Ma}$ (Achmad and Samuel, 1984) consistent with the cooling event dated at about 25 Ma based on apatite fission track data (Moss and Chambers, 1999).

Wilson and Evans (2002) describe heterolithic breccias containing angular clasts of limestone, siltstone, sandstone and quartzite (Landas Limestone Breccia) exposed in the northeast Mangkalihat Peninsula. The breccias are interbedded with outer neritic carbonates and upper bathyal marls that range in age from Late Eocene to Early Miocene (Wilson and Evans, 2002). The breccias represent clastic material shed from emergent highlands on the Mangkalihat Peninsula. The timing of uplift and shedding of clastics may correlate with the Late Eocene and Late Oligocene (van de Weerd and Armin, 1992) unconformities.

The presence of Upper Oligocene strata in the Makassar-A1 well and Upper Oligocene marls interbedded with the breccias in the northeast Mangkalihat Peninsula outcrops records a period of contemporaneous deposition in the basins and erosion on adjacent highlands and local uplifts during the Late Oligocene.

Tectonism at the end of the Early Miocene accentuated older structures formed during previous tectonic events. Erosion associated with Miocene uplift is marked in the offshore Mangkalihat uplift by a slight angular unconformity and onlapping seismic horizons (Figure 7). Pliocene east-west compression resulted in reactivation of northwesttrending faults and created the present day basin inversion anticlines.

\section{CONTAINMENT}

Oligocene to Miocene bathyal mudstones deposited in the basinal areas flanking carbonate deposits on the Mangkalihat Peninsula overlie the Late Eocene unconformity and form a regional top seal. Middle Eocene marine mudstones overlie Lower Eocene turbidite reservoirs in the Makassar-A1 and Birah-1 
wells, providing intraformational top and lateral fault seals for sub-unconformity traps.

Some structures (e.g., Birah and Makassar) have faults that reach the seafloor that could allow hydrocarbons to leak to the surface as indicated by the presence of thermogenic gas in seafloor cores (Decker et al., 2004). Eocene faults truncated at the Late Eocene unconformity could provide a migration pathway for hydrocarbon migration but these faults are adequately sealed by overlying mudstone units. Thief zones may exist where porous Upper Eocene carbonates onlap structures mapped at the top of the Late Eocene unconformity.

\section{PLAY RISK}

Although the specific source rock interval cannot be conclusively documented, the presence and quality of thermally mature source rocks are not considered to be a high risk component due to widespread offshore oil and gas shows and onshore hydrocarbon seeps and production. Seal risk is also low for Late Eocene buried-hill structures and Miocene folds that do not have faults extending to the seafloor. Sub-unconformity fault closures have higher risk due to the uncertainty in adequately mapping lateral seals.

The ability to map stratigraphic units below the Late Eocene unconformity is limited due to coarse 2D seismic line spacing and poor image quality of the vintage data. Because of these limitations, structural definition and reservoir quality are considered the highest risk elements.

\section{CONCLUSIONS}

The marine Eocene play described in this paper is a new deepwater play type in the Kutei basin. This play targets thick turbidite sandstone reservoirs in structures thought to be charged by unproven oilprone Eocene marine source rocks based on analogy with the successful deepwater Kutei basin Miocene turbidite play. The defined Eocene turbidite play area encompasses an area of approximately $5180 \mathrm{sq}$ $\mathrm{km}$ on the offshore southern Mangkalihat uplift where the Middle to Lower Eocene objectives occur at reasonable drilling depths (1500-3600 m).

Similar plays may exist in other areas where thick Eocene syn-rift marine deposits may also be present such as: 1) the Sambakung Formation in the Muara, Berau and Tarakan basins north of the Mangkalihat Peninsula, 2) the Budungbudung Formation in the
Lariang and Karama regions offshore western Sulawesi and 3) basinal equivalents of the MalawaToraja Formations offshore south Sulawesi.

\section{ACKNOWLEDGEMENTS}

We thank BPMIGAS and Anadarko Indonesia Company for permission to publish this paper, and Anadarko colleagues Ian Roberts and Wayne Muller for their input and review of seismic interpretations. The authors also wish to express our gratitude to MIGAS, PT Energi Consulting Indonesia, and PGS for providing new (2008) offshore seismic data over the Mangkalihit uplift and permission to publish the seismic lines contained in this paper.

\section{REFERENCES}

Achmad, Z. and Samuel, L., 1984, Stratigraphy and Depositional Cycles in the N.E. Kalimantan Basin: Proceedings of the Indonesia Petroleum Association $13^{\text {th }}$ Annual Convention, p. 109-120.

Chambers, J.L., Carter, C.I., Cloke, I.R., Craig, J., Moss, S.J., and Paterson, D.W., 2004, Thin-Skinned and Thick-Skined Inversion-Related Thrusting-a Structural Model for the Kutei Basin, Kalimantan, Indonesia, in McClay, K.R., ed., Thrust Tectonics and Hydrocarbon Systems: American Association of Petroleum Geologists Memoir 82, p. 614-634.

Curiale, J., Lumadya, E., and Lin, R., 2002, Petroleum and Source Rock Geochemistry of the Salayar Basin (Offshsore Sulawesi), Indonesia (abs.): American Association of Petroleum Geologists Annual Meeting, Houston, Texas.

Curiale, J., and Decker, J., 2007, Eocene Oil-Prone Source Rock Potential of Central Indonesia (abs.): American Association of Petroleum Geologists Annual Meeting, Long Beach, California.

Decker, J., Teas, P.A., Curiale, J.A., Johnson, E.A.E., and Orange, D.L., 2004, Multibeam Exploration in the Makassar Strait: Proceedings of the Indonesia Petroleum Association-American Association of Petroleum Geologists Deepwater and Frontier Symposium, Jakarta, Indonesia, p. 11-30.

Djamal, B., Sudana, D., Soetrisno, Baharuddin, and Hasan, K., 1995, Geological Map of the Tanjung Mangkalihat Sheet, Kalimantan: Geological Research and Development Centre, Bandung, Indonesia, Scale 1:250,000. 
Doust, H., and Noble, R.A. 2008, Petroleum Systems of Indonesia: Marine and Petroleum Geology v. 25, p. 103-129.

Dunham, J. B., Lin, T. J., Readhead, H. F., Schwing, H. F., and Shirley, S. H., 2000, Transport and Concentration of Gas and Oil-Prone Kerogens into Deep Water Sediments of Kutei Basin, East Kalimantan, Indonesia (abs.): American Association of Petroleum Geologists International Conference Program with Abstracts, p. A23.

Feriansyah, L.T., Chambers, J.L.C., Dewantohadi, S.H., Syaiful, M., Priantono, T., and Imanhardjo, D.N., 2000, Structural and Stratigraphic Framework of the Palaeogene in the Northern Kutei Basin East Kalimantan: Proceedings of the Indonesia Petroleum Association $27^{\text {th }}$ Annual Convention, p. 1-14.

Folk, R.L., 1974, Petrology of Sedimentary Rocks: Austin, Texas, Hemphill Publishing Company, 182 p.

Fukasawa, H., Sunaryo, R., and Napitupulu, P.H., 1987, Hydrocarbon Generation and Migration in the Sangatta Area, Kutei Basin: Proceedings of the Indonesia Petroleum Association $16^{\text {th }}$ Annual Convention, v. 1, p. 123-139.

Gradstein, F.M., Ogg, J.G., and Smith, A.G., eds., 2006, A Geologic Time Scale 2004: Cambridge University Press, 610 p.

Guritno, E.E. and Chambers, J., 2000, North Runtu PSC: the First Proven Eocene Petroleum Play in the Kutai Basin: Proceedings of the Indonesia Petroleum Association $27^{\text {th }}$ Annual Convention, p. 1-20.

Guritno, E., Salvadori, L., Syaiful, M., Busono, I., Algar, S., Mortimer, A., Hakim, F.B., and Decker, J., 2003, Deep Water Kutei Basin: A New Petroleum Province: Proceedings of Indonesian Petroleum Association 29th Annual Convention, v. 1., p. 1-22.

Hall, R., 2002, Cenozoic Geological and Plate Tectonic Evolution of SE Asia and the SW Pacific: Computer-Based Reconstructions, Model and Animations: Journal of Asian Earth Sciences, v. 20, p. 353-434.

Howes, J.V.C., 1997, Petroleum Resources and Petroleum Systems of SE Asia, Australia, Papua
New Guinea, and New Zealand, in, Howes, J.V.C., Noble, R.A., eds., Proceedings of an International Conference on Petroleum Systems of SE Asia and Australasia: Indonesian Petroleum Association, p. 81-100.

Lin, R., Saller, A., Dunham, J., Teas, P., Kacewicz, M., Curiale, J., and Decker, J., 2005, Source, Generation, Migration and Critical Controls on Oil versus Gas in the Deepwater Kutei Petroleum System: Proceedings of the Indonesia Petroleum Association $30^{\text {th }}$ Annual Convention, p. 447-466.

Longley, I., 2005, Topical Tropical Non-Marine Deep Water Deltaic Charge Systems in SE Asia. A Model to Explain Why Some are Oily and Some are Not: Proceedings of the Indonesia Petroleum Association $30^{\text {th }}$ Annual Conference, p. 625-646.

Moss, S.J., and Chambers, J.L.C., 1999, Tertiary Facies Architecture in the Kutai Basin, Kalimantan, Indonesia: Journal of Asian Earth Sciences v. 17, p. 157-181.

Moss, S.A., and Chambers, J.L.C., 2000, Depositional Modeling and Facies Architecture of Rift and Inversion Episodes in the Kutai Basin, Kalimantan, Indonesia: Proceedings of the Indonesia Petroleum Association $27^{\text {th }}$ Annual Convention, p.1-22.

Noon, S., Harrington, J., and Darman, H., 2003, The Tarakan Basin, East Kalimantan: Proven Neogene Fluvio-Deltaic, Prospective Deep-Water and Paleogene Plays in a Regional Stratigraphic Context: Proceedings of the Indonesia Petroleum Association $29^{\text {th }}$ Annual Convention, v. 1, p. 1-14.

Paterson, D.W., Bachtiar, A., Bates, J.A., Moon, J.A., and Surdam, R.C., 1997, Petroleum System of the Kutei Basin, Kalimantan, Indonesia: Proceedings of the Indonesia Petroleum Association Petroleum Systems of SE Asia and Australasia Conference, p. 709-726.

Peters, K.E., Snedden, J.W., Sulaeman, A., Sarg, J.F., and Enrico, R.J., 2000, A New GeochemicalSequence Stratigraphic Model for the Mahakam Delta and Makassar Slope, Kalimantan, Indonesia: American Association of Petroleum Geologists Bulletin, v. 84, p. 12-44.

Saller, A., Lin, R., and Dunham, J., 2006, Leaves in Turbidite Sands: the Main Source of Oil and Gas in the Deep-Water Kutei Basin, Indonesia: American Association of Petroleum Geologists Bulletin, v. 90, p. $1585-1608$. 
Satyana, A.H., and Biantoro, E., 1996, Seismic Stratigraphy of Eocene Beriun Sands of West Bungalun, East Kalimantan, Indonesia: a Contribution to the Paleogene Stratigraphic Knowledge of the Kutei Basin: Proceedings of the International Symposium on Sequence Stratigraphy in S.E. Asia, p. 383-393.

Sukardi, Djamal, B., Supriatna, S., and Santoso, S., 1995, Geologic Map of the Muaralasan Quadrangle, Kalimantan: Geologic Research and Development Center, Bandung, Indonesia, Scale 1:250,000.

Sunaryo, R., Martodjojo, S., and Wahab, A., 1988, Detailed Geological Evaluation of the Possible Hydrocarbon Prospects in the Bungalun Area, East Kalimantan: Proceedings of the Indonesia Petroleum Association $17^{\text {th }}$ Annual Convention, v. 1, p. 423- 446.

Van de Weerd, A.A., and Armin, R.A., 1992, Origin and Evolution of the Tertiary Hydrocarbon-
Bearing Basins in Kalimantan (Borneo), Indonesia: American Association of Petroleum Geologists Bulletin, v. 76, p. 1778-1803.

Wilson, M.E.J., Chambers, J.L.C., Evans, M.J., Moss, S.J., and Nas, D.S., 1999, Cenozoic Carbonates in Borneo: Case Studies from Northeast Kalimantan: Journal of Asian Earth Sciences, v. 17, p. 183-201.

Wilson, M.E.J., and Evans, M.J., 2002, Sedimentology and Diagenesis of Tertiary Carbonates on the Mangkalihat Peninsula, Borneo: Implications for Subsurface Reservoir Quality: Marine and Petroleum Geology, v. 19, p. 873-900.

Wilson, M.E.J., Evans, M.J., Oxtoby, N.H., Satria Nas, D., Donnelly, T., and Thirlwall, M., 2007, Reservoir Quality, Textural Evolution, and Origin of Fault-Associated Dolomites: American Association of Petroleum Geologists Bulletin, v. 91, p. $1247-1272$. 


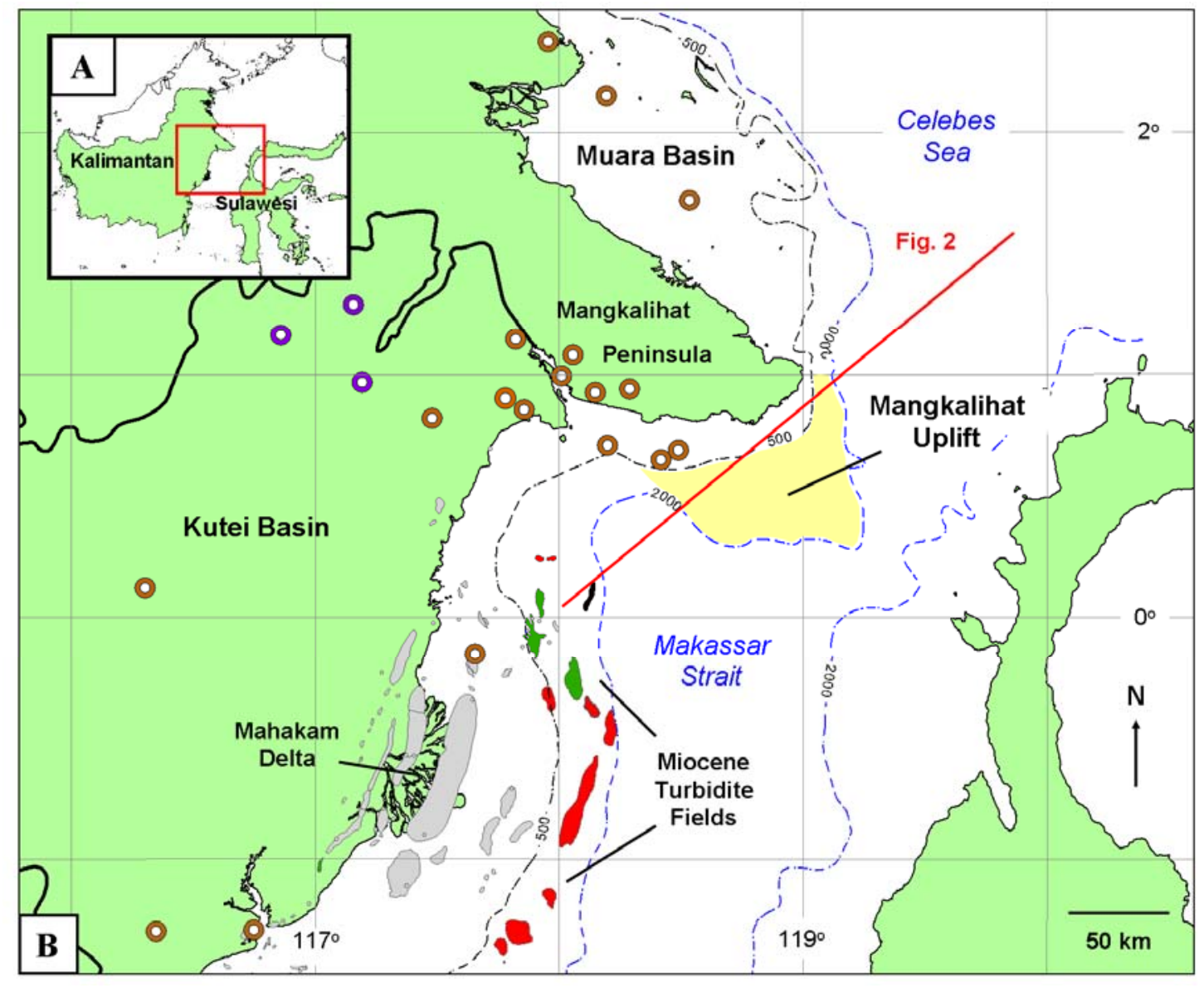

Figure 1 - (A) Location map of northern Makassar Strait between Kalimantan and Sulawesi, Indonesia and (B) location of Eocene turbidite play on offshore Mangkalihat uplift (yellow). Deepwater Kutei basin Miocene turbidite fields colored red (gas) and green (oil). Wells that have reached the Eocene and pre-Tertiary basement are shown by brown and purple circles, respectively. Bathymetric contours in meters. 


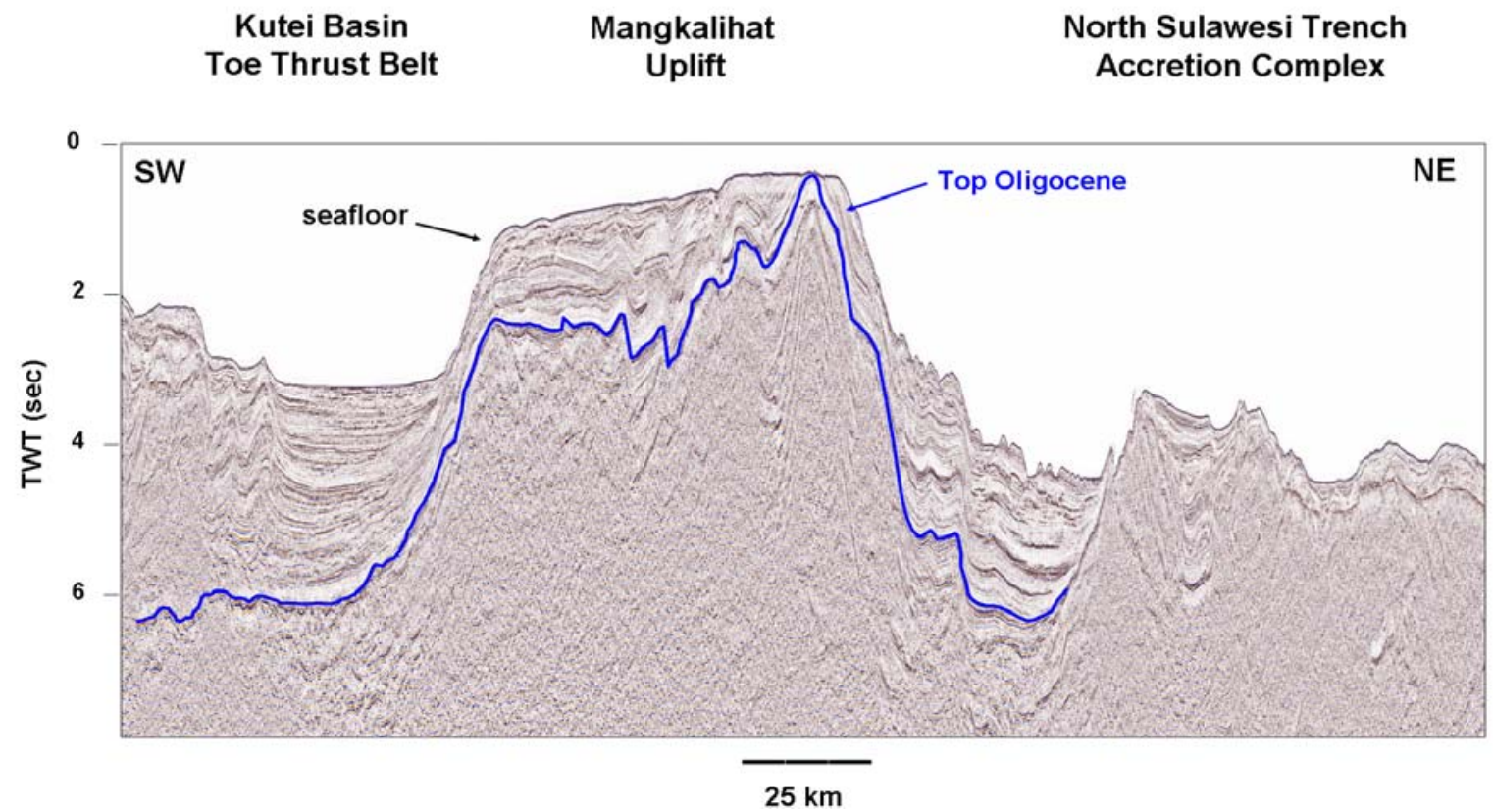

Figure 2 - Regional 2D seismic line over Mangkalihat uplift extending northeast from Kutei basin toe thrust belt to north Sulawesi trench. Location of seismic line shown in Figure 1. Synrift Eocene strata occur below top of Late Oligocene unconformity shown in blue. Vertical exaggeration approximately $17 x$ at the seafloor. Seismic data courtesy of MIGAS, PT Energi Consulting Indonesia and PGS. 


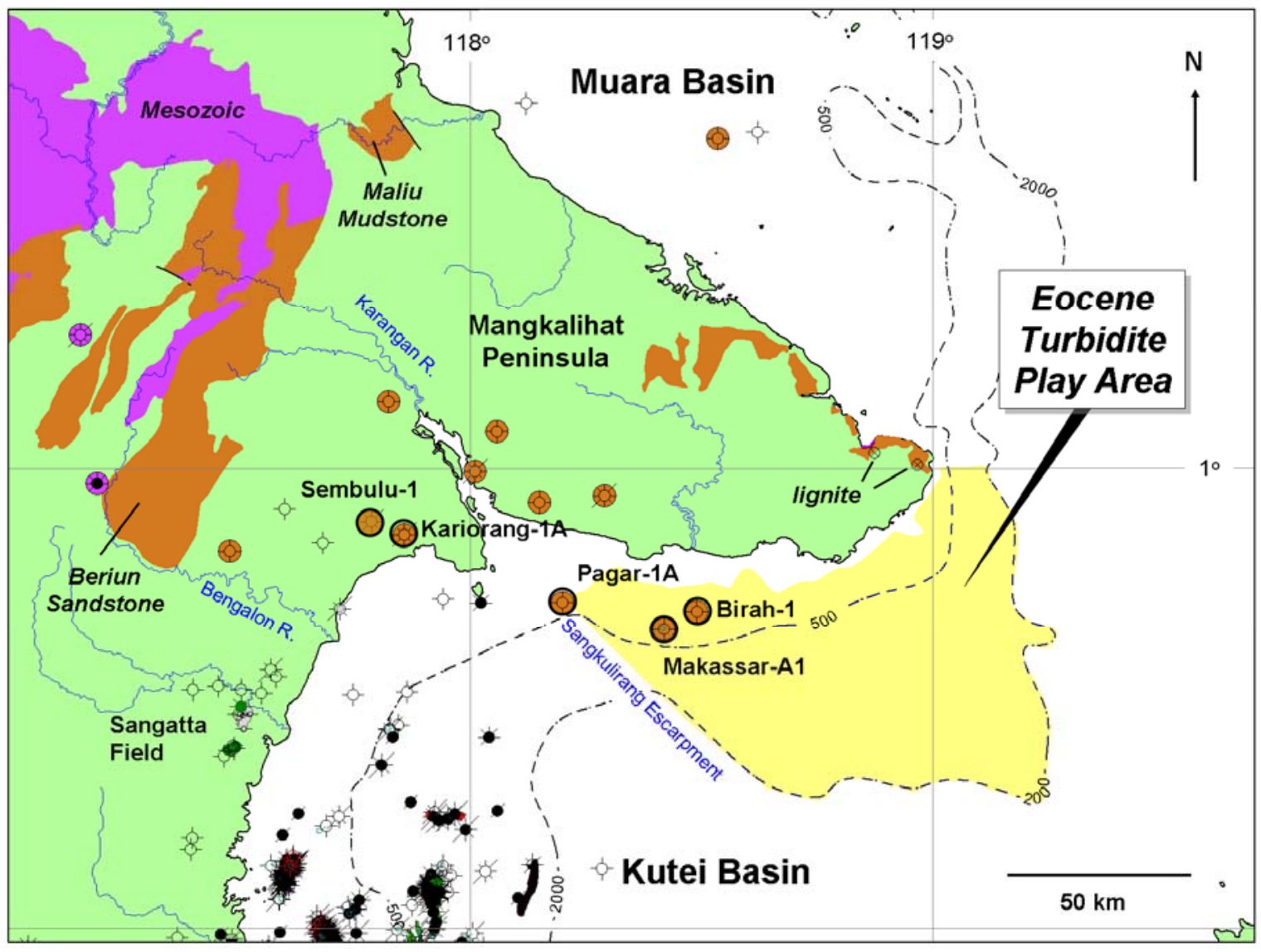

Figure 3 - Map of northern Kutei basin and Mangkalihat Peninsula area showing location of Eocene turbidite play area on offshore Mangkalihat uplift. Eocene and pre-Tertiary basement outcrops and well penetrations shown by brown and purple colors, respectively. Well names discussed in text highlighted. Bathymetric contours in meters. 


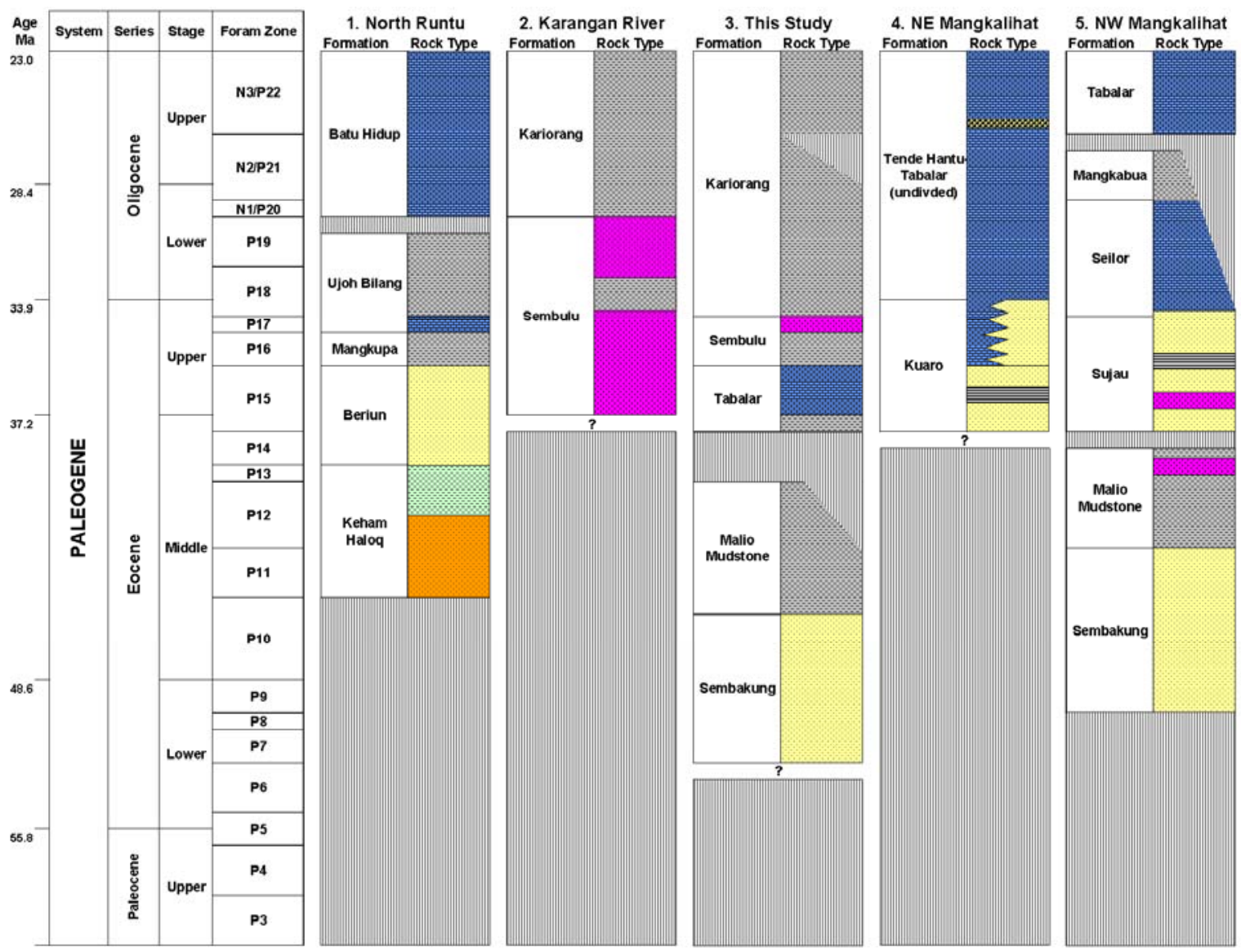

Figure 4 - Paleogene stratigraphic correlation chart of northern Kutei basin and Mangkalihat Peninsula. Location of stratigraphic columns shown on inset map. 


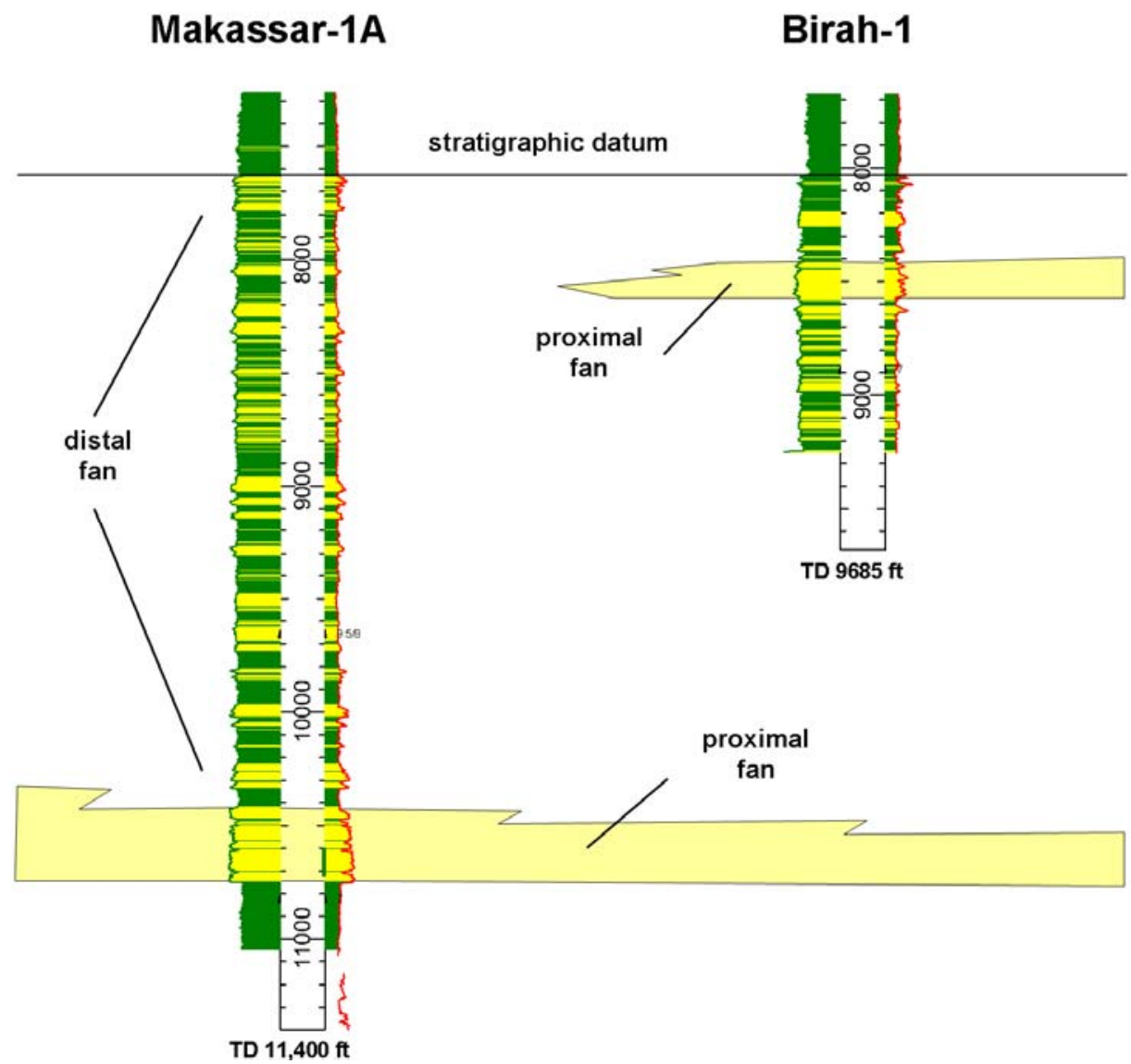

Figure 5 - Stratigraphic cross section illustrating electric log character of proximal and distal turbidite sandstones (yellow) in Makassar-A1 and Birah-1 wells. Gamma-ray curve (left) and resistivity curve (right). Measured depths in feet. 


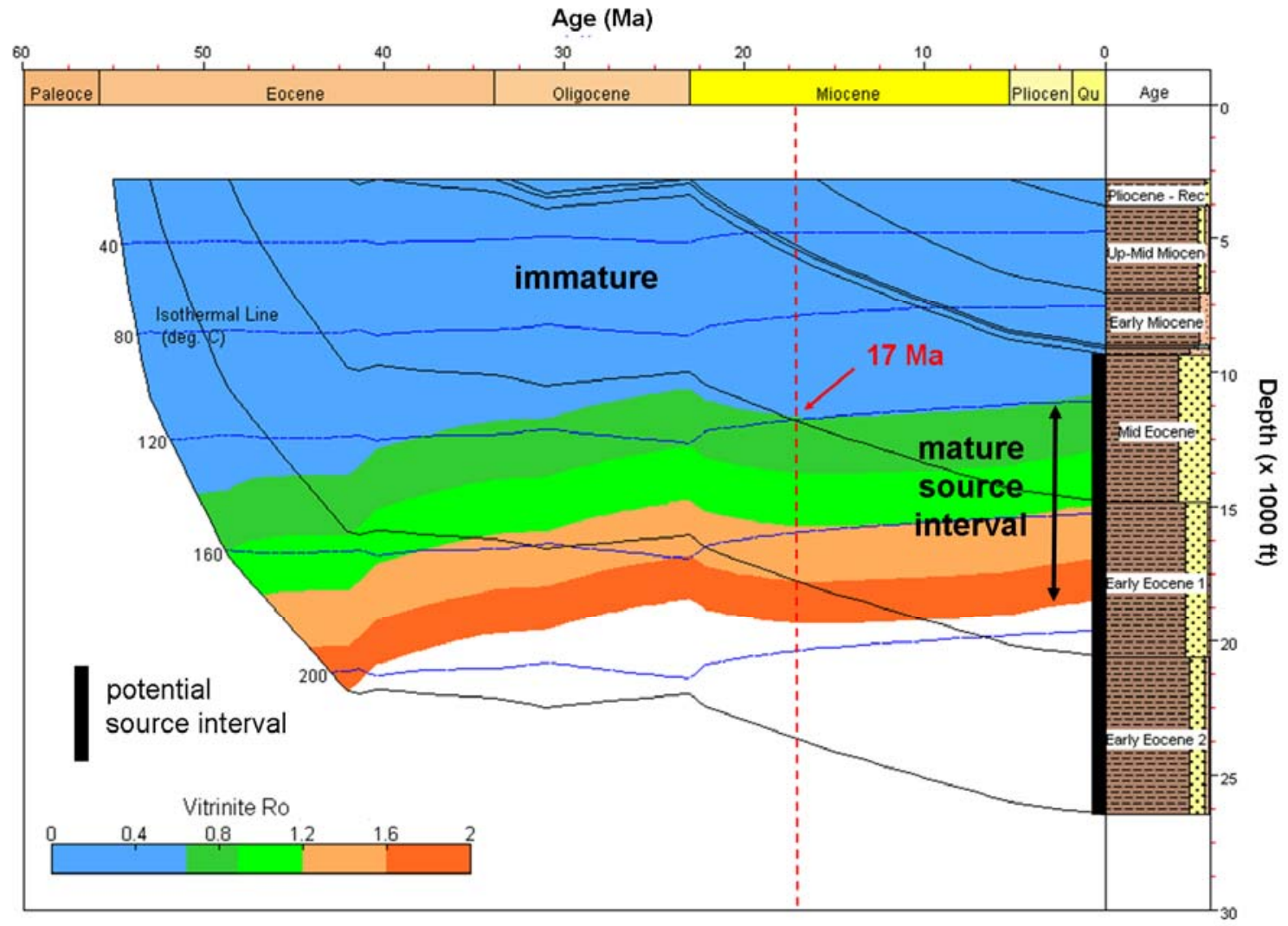

Figure 6 - Burial history plot for potential source kitchen on Mangkalihat uplift showing thermally mature Middle to Lower Eocene interval. At this location, the top of the Lower Eocene potential source rocks entered the oil window ( $0.7 \%$ Ro) at the end of the Early Miocene (approximately $17 \mathrm{Ma}$ ). The Middle to Lower Eocene source interval is presently oil and gas mature. 


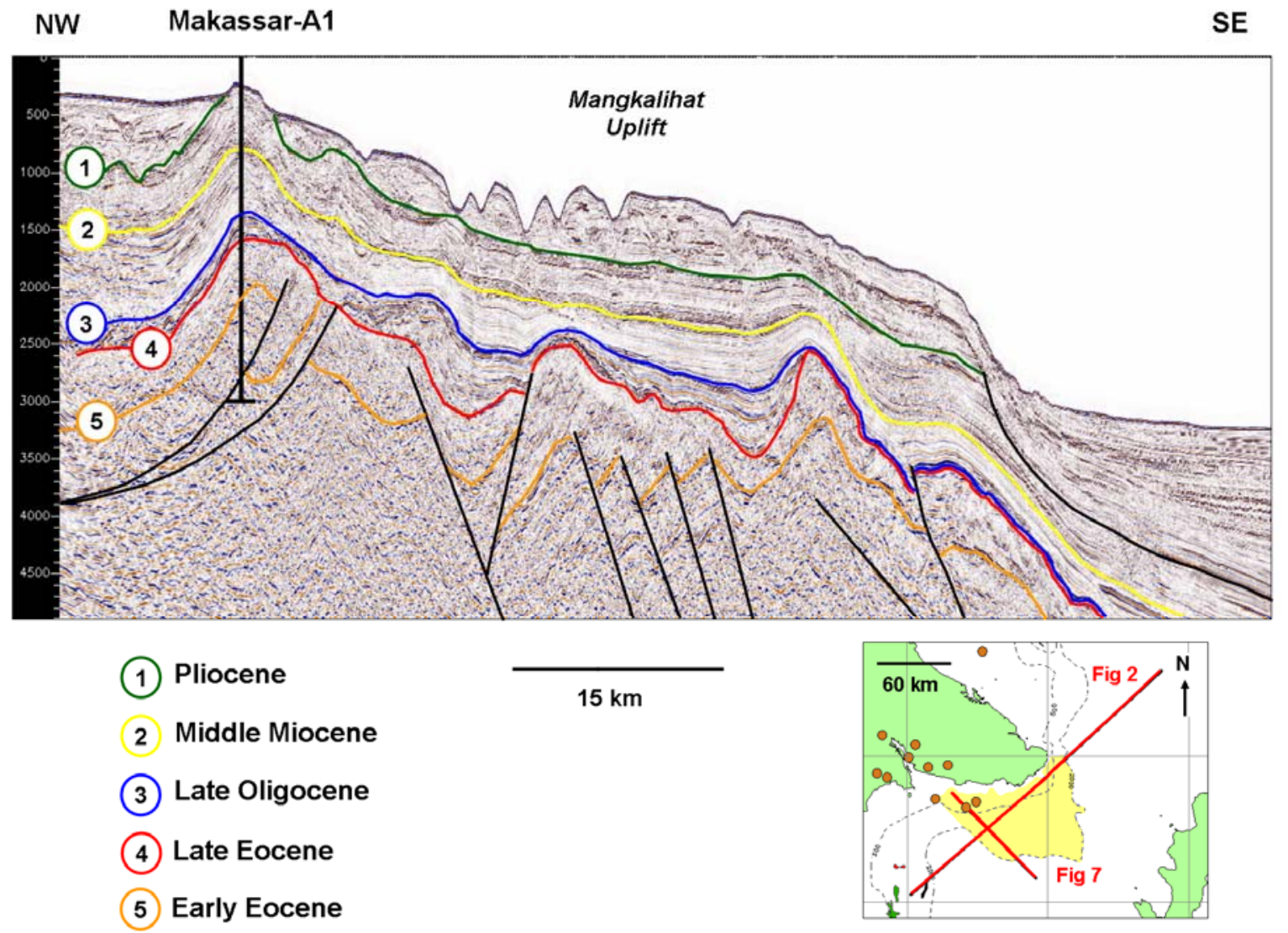

Figure 7 - 2D seismic line over Mangkalihat uplift showing deformed Tertiary strata and major unconformities labeled 1-4. Folded and faulted Middle to Lower Eocene strata are truncated by Late Eocene angular unconformity (4). Location of seismic lines shown on inset map. Vertical exaggeration approximately $10.5 \mathrm{x}$ at the seafloor. Seismic data courtesy of MIGAS, PT Energi Consulting Indonesia and PGS. 